\title{
Attentional Factors in Easter Eggs Choice by Children
}

\author{
Luise Kipper1 \\ Roberto Guedes de Nonohay2
}

\section{Resumo}

O mercado voltado para crianças continua crescendo ao longo dos anos. No entanto, algumas permanecem pouco exploradas. Ovos de Páscoa é um exemplo. A estratégia de marketing é oferecer diferentes tipos de brinquedos ou ter um personagem popular na embalagem. Este artigo tem como objetivo compreender quais fatores em um ovo de Páscoa atraem mais atenção: brinquedos, personagens ou sabor. Um eyetracker foi usado para identificar a atenção e a fixação do olhar durante a exploração das imagens. Quarenta crianças, com idade entre sete e dez anos, participaram do experimento. Os resultados mostraram que os ovos de chocolate clássicos foram preferidos tanto pela escolha quanto pelo tempo médio de fixação, sugerindo que o sabor é um critério de escolha prevalente.

Palavras-chave: Neuromarketing; Comportamento do consumidor infantil; Eyetracker.

\begin{abstract}
The market targeting children keeps growing over the years. However, there are some areas which remain little explored. Easter eggs is such an example. The marketing strategy is to offer different types of toys or prizes inside or have a popular character appear in the packaging. This article aims to understand what factors in an Easter egg attracts more attention: toys, characters or flavor. An eyetracker was used to identify gaze attention and fixation during images exploration. Forty children, aged between seven and ten years-old, took part in the experiment. Results showed that the classic chocolate eggs were preferred both by self reported choice and mean fixation time, suggesting that flavor, not toys or characters, was a prevalent choice criterion.
\end{abstract}

Keywords: Neuromarketing; Children's consumer behavior; Eyetracker.

\footnotetext{
${ }^{1}$ Universidade do Vale do Taquari - UNIVATES, Rio Grande do Sul (Brasil). Email: lukipper@hotmail.com

2 Faculdade Meridional - IMED, Rio Grande do Sul, (Brasil). Email: rgnonohay@gmail.com
}

Recebido em 14.08.2018

Aprovado em 13.12.2018

\section{Revista Administração em Diálogo}

ISSN 2178-0080

Programa de Estudos Pós-Graduados em Administração

Pontifícia Universidade Católica de São Paulo 


\section{Introduction}

With so many choices of products, brands, flavors, colors and types of packaging, purchase decisions have become more difficult to predict. Understanding consumer behavior is one of the most difficult tasks bestowed on a marketer, because consumers often do not know what they want or what their needs and preferences are (Camargo, 2013). Most of the uncertainty is due to the difficulty in obtaining reliable and replicable answers in self reports and purchase behavior. Neuromarketing can help to understand behavior through the perspective of the consumers' brains and psychological traits, and can able to aid the effort to market products or services that best suits consumers' needs (Morin, 2011). This makes it easier for consumers to make decisions, and allow companies to invest in the right products and marketing strategies, avoiding misallocation of investment. There are several factors that can influence decisions such as cultural, social, personal or psychological (Kotler, \& Keller, 2012). Parents are very much influenced by one single social factor: children. They influence parents' purchasing decisions, both in the acquisition of products for the family and for themselves (Calvert, 2008). Thus, a major share of investment in advertisement is focused on children, increasing their influence in family decision making.

This article aims to better understand children's consumer behavior, specifically when choosing an Easter egg. Many companies use characters and other features in their packaging to specifically attract children (Silva, \& Vasconcelos, 2012). For Easter eggs - especially in Brazil - this is a very common marketing strategy: chocolate manufacturers, through licensing, display characters and provide gifts on the Easter egg packaging to attract attention. An experiment was developed to verify which kind of Easter egg was able to attract children's attention and preference. Different packaging and licensing attempts by chocolate manufacturers actually attract children's attention and result in purchase preference. In this sense, we sought to investigate if one or more of the following aspects is more effective at attracting children's' attention: 1) the characters; 2) the gifts (toys); 3) or the classic eggs (no characters or toys, only chocolate). In order to measure attention during preference statement an eyetracker was used to measure gaze fixation. It is assumed that children 
would prefer Easter eggs according to the character or gift available and marketed in the packaging.

\section{Literature Review Infant consumer behavior}

There are four factors that influence consumer buying behavior: cultural (which is the most influential), social (through group influence), personal (individual characteristics), and psychological factors (motivation, attention, etc.) (Kotler, \& Keller, 2012). Companies seek to identify their customers by investigating who buys their products, what influences them, how the decision making process is done, where and why customers buy, how the products are perceived, amongst other factors (Kotler, \& Keller, 2012). This process can be applied both to adults and children. Therefore, companies will strive to access their public in different ways. Children tend to act more according to social and cultural aspects, given that they have a more pressing need to form and be part of social groups. In most cases, children, however, do not possess the means to buy the products or services that they desire. They depend mostly on their parents money to do so.

In this sense, according to Kotler and Keller (2012), children and adolescents have a direct and indirect influence on family purchases. Direct influence refers to their requests and requirements, and indirect influence is when the parents already know the preferences of their children regarding brands or products. Many parents do not have enough time to reconcile work and other activities with the care of their children (Silva, \& Vasconcelos, 2012). In this sense, they end up giving up more easily to their requests. This bestows on children more power of influence in the decision making process and family buying behavior As it will be discussed below, children have different aspects that are taken into consideration in a buying scenario. When those differences are added to the influence they have on their parents and the virtual lack of worries regarding money, they are an important group of consumers. Those who buy mainly out of desire, with little or no regard to financial matters.

Young people tend to follow the same decision steps as adults, however, some developmental differences need to be considered. Costa, Lima and Santos (2012),

\section{Revista Administração em Diálogo}

ISSN 2178-0080 
discuss that children initiate the process of buying at one month of age, when they go to the supermarket with their parents and observe them choosing and buying products. Then, from the age of two, they start asking for products they see in windows or on television. Soon thereafter, they already select the products they want. The next step is to choose and buy with the help of their parents, on average at age five, when they already understand what money stands for. Finally, at the age of eight, they will start to shop by themselves.

Still regarding the developmental stages, Silva and Vasconcelos (2012), state that children up to two years of age are more easily controlled by their parents, because they easily entertain themselves with other options available to them. At this point, they like to bite, touch and experience everything around them in order to know their surroundings. From two to four years of age, the child has already developed his system of language, cognitive ability and personality, so they begin to choose products according to his preferences. From the age of three he is able to identify brands and is able to choose a product by analyzing its packaging, and during this phase he associates images of famous characters and people with their respective products. From five to seven years, they use different criteria of choice as taste and functionality for example. At this time, children begin to undergo influences from friends, and they become more influenced by the choices of the members of the group. In addition, Karsaklian (2012) states that between five and six years old, children search for immediate pleasure, they like many colors, pieces in movement and prefer stores which stimulates dreams and fantasy. From the age of seven, the child already knows brands and understands that their concept is related to a commercial objective, and tends to confront parents and to get immersed in the social group of which they are part of. Between seven and nine years old children like innovation, they value money and they like to try on things, because they are very curious. Girls from ten to twelve years old like to take care of their beauty, so they like clothes, accessories and beauty products. Boys in this age, on the other hand, like products which represent strength, power and money.

Calvert (2008) explains that the number of children's television channels and children's internet sites grew because of the increased influence of children on family purchase decisions. To connect with this audience, marketers advertise on TV channels or magazines for kids. Until the age of five, children do not know the difference 
between a TV show and an advertisement (Limeira, 2008). They will start to perceive the difference when they reach the age of eight. On TV the most advertised products for children are cereals, fast food restaurants, sweets and toys, but they can also influence parental decisions in situations such as buying a new car, choosing a meal, and vacationing (Calvert, 2008). Silva and Vasconcelos (2012) also comment on the use of cartoon characters in product packaging, through licensing, to attract children's attention. In this way, they often choose the product of such a character, rather than choosing the product of such flavor, such brand or such functionality. The use of characters, according to the authors, can form affinity groups among children, for example, girls who like the character $\mathrm{X}$ or boys who like the design $\mathrm{Y}$. On the other hand, Karsaklian (2012) affirms that perceiving a brand on an advertisement does influence children's choices. Children between eight and ten years old have demonstrated that the fact of seeing a brand on advertisements increase the chance of them choosing this brand due to perceived credibility. The advertisement effort is aimed at facilitating the remembrance of the brand through positive and affective connections. To advertise the features of the product assertively, one must use movements, sound effects and loud music. And using characters, celebrities or gifts helps increase interest in the products, as long as they are attractive to children (Calvert, 2008). In addition to these factors, Karsaklian (2012) provides further examples of advertisement strategies: fun advertisements, the use of cartoons, jingles, the presence of animals or elderly people (reminding them of their grandparents) and evidence of values important to children (being strong, a hero or a good friend).

Given what was exposed above, the main hypothesis presented is that Easter eggs with gifts will attract more attention due to the reward and social influence associated with the purchase.

\section{Neuromarketing}

Marketers typically use marketing research to seek consumer responses about a product or brand. However this type of research might not reveal what the consumer really thinks. Often, because they themselves cannot remember everything they wish to convey to the researcher or, for some reason, do not reveal the whole truth (Camargo, 2013). The purpose of marketing research is to combine products with 
people, creating product designs that are compatible with consumer preferences, thus facilitating the process of choosing which product to buy (Ariely, \& Berns, 2010). To that end, before the product is released, marketers study what the target audience wants and define how and to who sell the product. There are several ways to perform a research as accurate as possible. One way to better understand the consumer's mind would be through psychophysiological research, the main techniques used in neuromarketing today (Ariely, \& Berns, 2010). Psychophysiological research is focused on finding the behavioral and psychological correlates of physiological phenomena, such as variances in brain waves, heart beats, skin conductivity, eye movements, amongst others. In so using it to obtain marketing responses is becoming more popular due to operational cost reductions and the speed that new studies are being published. This method is more effective than others because it can discover undisclosed information in the consumers' behavior, especially if combined with other methods.

Morin (2011) states that neuromarketing emerged from 2002 onwards, mixing neuroscience with marketing. It aims to study the behavior of consumers through the perspective of their nervous systems and behavioral correlates. The first research related to the subject was an adaptation of the "Pepsi Challenge" using a Functional Magnetic Resonance Imaging (fMRI), a device that monitored participants' brains. In a blind taste test, participants would choose Pespi, however, when shown the labels, participants would choose Coca-Cola. Morin (2011) concludes that Coca-Cola, due to strong consumer connection, reaches a part of the consumer's frontal cortex, which is the region of the brain that is said to control attention, short-term memory and planning. In the case of the blind taste choice, in which Pepsi was preferred, it is said that the limbic system that was more active, which is related to the control of emotional behavior.

Other equipment can be used to gauge neuroscientific data and its correlated behaviors. Engelke et al. (2017) provide a list of equipments that can be used: focusing on the Central Nervous System (CNS), electroencephalography (EEG), which uses electrodes on the scalp that are able to verify changes in the electrical activity in cortical regions; near-infrared spectroscopy (NIRS), which is similar to fMRI, with less spatial resolution; focusing on the Autonomic Nervous System (ANS), electrocardiogram (ECG), which measures oscillations in heart rate, and electrodermal 
activity (EDA), which measures differences in skin conductance levels. One other equipment used in neuromarketing research is the eyetracker (Engelke, et al., 2017). It measures gaze patterns and fixation. It is a useful tool to investigate attention and perception in adults and children, both highly important factors in marketing research.

Therefore there is a significant amount of information that can be obtained using neuroscientific tools and techniques that will provide researchers and marketers with very useful information about the consumer and its behavior. Those tools might be able to reveal information that otherwise would not be obtained via self report or big data analysis, for example. That is true for adults and also for children.

\section{Child's brain and behavior}

Neurons begin to be produced when the human being is about 10 weeks in the conception cycle, and at 28 weeks of life, practically reaches the maximum number of neurons he will have in his entire life. First, neurons from the innermost layer are positioned, and so on, until they form the six layers of the brain, from the innermost to the outermost. This process takes about seven months. At four months of age, neural transmission of babies starts to become faster, due to the myelin that begins to attach to axons. This process happens until the adolescence of individuals, and their abilities improve over time. "Neurons that carry sensory information are the first to acquire myelin; the neurons of the cortex are among the last" (Kail, 2004, p. 113). This means, for example, that the child will walk soon, but it will take time to form their personality and understand behaviors. Bee and Boyd (2011) argue that at birth, the most developed parts of the baby's brain are the midbrain and medulla, which control respiration, heart rate, general attention, sleep, and movements of the head and neck. Like Kail (2004), Bee and Boyd (2011) claim that the cerebral cortex is the last to develop. According to the authors, only between the ages of 10 and 12 do the cortex and frontal lobes become the focus of development. And between the ages of 13 and 15 there is yet a deep change in the prefrontal cortex, related to executive processing, so that the child processes and controls their thoughts and behavior in a more advanced manner. On the other hand, Martorell (2014) states that the lobes responsible for vision, hearing and other sensory information are already mature at only six months of age.

\section{Revista Administração em Diálogo}

ISSN 2178-0080 
Bee and Boyd (2011) discusses Piaget's four stages of how babies, and then children, receive influence the environment. The first is the sensorimotor stage, from birth to two years, in which the baby develops the knowledge of the senses and motor skills; from two to six years, he develops the pre-operational stage, which is when he begins to use words and numbers, but only subjectively; the stage of concrete operations, developed from seven to eleven years, represents the stage at which the child begins to use logic; and, finally, the stage of formal operational thinking, from adolescence onwards, in which the individual is able to organize ideas and think logically about abstract and uncertain situations. Martorell (2014) states that children's learning progress is related to progress in school grades. Thus, the more they learn, the more they increase their ability to pay attention, to retain information in memory, and to plan and control their behavior. Bee and Boyd (2011) further compliment that a six-year-old child, compared to a five-year-old, has a greater ability to understand complex ideas and is more responsible. Also in those ages, the authors say that children often pay less attention to appearance (of themselves, of people around them, and of objects) and more attention to the underlying reality. As it is, children are still in important developmental stages when they first begin to receive marketing information regarding toys and TV shows, for example. They are in their formative years and so one of the most important aspects is their attention. They begin to understand and relate to different stimuli in the environment and can focus primarily on colorful and positive stimuli. Such stimuli are those presented by companies which target children as their main audience. That is particularly true for the Easter egg manufacturers. Therefore, it is important to better understand how different marketing stimuli affect children behavior and purchase preferences. However, it would be interesting to focus on biological factors as well. Bodily automatisms, such as dilation of the pupil, brain behavior, acceleration of the heart beats, sweating of the hands, facial micro expressions, among others, may aid the understanding of the consumer and his or hers behavior. As such, the psychological factors (Kotler, \& Keller, 2012), are mainly originated and processed in the brain, which further increases the importance of understanding the functioning of the brain and its psychophysiological correlates. Obtaining self-report answers about the consumer is important. However, it is only a small part of the information available. It is necessary that the correct 
equipment and research methods be applied given that, in many cases, it is not possible to obtain reliable answers only through self-report and purchase data (Camargo, 2013). Consumers tend to respond to marketing research in a rational way, without verbalizing their emotions and automatic thoughts. However, emotions and automatic behaviors are especially difficult to assess using questionnaires and self reports.

Given what was exposed and the importance of knowing the effects of advertisement in children, the objective of the present study was to verify which factors attract children's attention when choosing an Easter egg. An eyetracker was used to verify their gaze and fixation patterns as they chose from different types of Easter eggs presentations. The main purpose of the eyetracker is to measure the attentional patterns resulting from higher level cognitive factors (Engelke et al., 2017) in response to the visual stimuli of different presentation of Easter eggs. In this way, it was sought to investigate if one or more of the following aspects is more effective at attracting children's' attention: 1) the characters; 2) the gifts (toys); 3) or the classic eggs (no characters or toys, only chocolate).

\section{Method}

An experiment was performed with children in order to understand what most attracts their attention when considering Easter eggs. This research was approved by the Universidade do Vale do Taquari's Ethics Committee. An eyetracker was used to measure gaze and fixation patterns. Also, self report measures of preference for Easter eggs were collected. With this setup it was able to check if the self reported preference were similar to the attentional behavior as measured by the eyetracker and which of the individual marketing strategies would attract children's attention the most.

\section{Participants}

Participants in the research were children aged seven to ten. The choice of this minimum age was due to the study of Silva and Vasconcelos (2012), who affirm that at seven years old the child already has developed language system, cognitive ability, own personality, besides being able to choose a product by their packaging and can also associate images of characters with their respective products. Moreover, at this age

\section{Revista Administração em Diálogo}

ISSN 2178-0080 
they know how to identify features of a product, as well as they use flavor as the criterion of choice and begin to be influenced by friends. In addition, from the age of seven the child recognizes brands and understands that it is related to a commercial objective. The study was carried out at a primary school in the city of Lajeado, Rio Grande do Sul. The school made possible the communication with the parents and/or guardians so that they could be present on the day of the data collection, or to authorize a school official to represent them. Parents and/or guardians received, read and signed the Informed Consent Form. Children also read and signed a Term of Assent accompanied by parents/guardian or school official, stating that they agreed to participate in the experiment. The sample consisted of 50 children, following the study by Fiszman et al. (2013), which used the same number of participants. In addition, this is the average quantity if one takes into account other studies, such as Huang and Kuo (2012), Cyr, Head and Larios (2010) and Fiszman et al. (2013). A total of 60 Consent Forms were delivered to the parents, 40 of which were signed (66.70\%). Of the 40 children that participated, 15 were girls. Due to lack of acceptable data (head movement, blinks and failure in the calibration process), five participants were excluded from the analysis. No new data collection was performed because, based on other researches with children and eyetracker, such as those by John et al. (2010), Acosta et al. (2013), Manders et al. (2010) and Lukasova (2012), and the studies cited above, a final sample of 35 was deemed satisfactory for the purposes of this study. Therefore, the distribution of age in the sample is as follows: 13 children aged seven years old (eight males and five females); one eight-year-old male; 20 nine-year-olds (thirteen males and seven females); and one 10-year-old female child. The research was carried out with two classes of fourth year of elementary education and a second year of elementary school, according to the availability of the school and acceptance of both children and parent/guardian. All participants stated that they had normal or corrected to normal vision and that they were not color-blind. In addition, they did not have the self-reported diagnosis (by themselves or their parents) of psychological disorders. 


\section{Instruments}

Of all the equipment described in the Neuromarketing section, we chose to work with the eyetracker for the following reasons. It is the most indicated to measure attentional factor and when children are considered, it is operationally easier to work with. Two Eyetribe eyetrackers (Eyetribe, Copenhagen, Denmark), with a $60 \mathrm{~Hz}$ sampling rate were used. It is a non-invasive device that verifies the positioning of the participant's gaze on the computer screen during the task. Two Dell laptops with 15.6inch screens were used to present stimuli and record data, one of them was a Vostro 3550 and the other an Inspiron 15. The Ogama 5.0 (Voßkühler et al., 2008) software was used for data acquisition and stimuli presentation. The eyetracker allows light head movements, without prejudice to data collection. For this reason, the participants did not need to be placed on a chin rest. Participants were seated during the experiment and the distance from the screen was of about 50 centimeters on average. Due to the space provided by the school, no type of luminance control was made, however, data collection was performed during a sunny day. Therefore, no problems with luminance are to be expected in the collected data.

\section{Stimulus}

Nowadays, especially for children, Easter has a more commercial value than a spiritual one, because gifting a relative or friend with chocolate eggs has become a very strong tradition in some countries, especially in Brazil. Today Easter eggs are seen as a consumer object that attracts great sums of money and advertisement budget.. Children are the main target audience of chocolate egg companies. Each manufacturer has several options for chocolate and gifts. Lunch boxes, umbrellas, coloring boxes, assorted toys, are among the examples. Each year companies plan new eggs with different characteristics and the development process of said eggs can begin up to 15 months before they start selling. This demonstrates the commitment and planning necessities of the chocolate companies to target children. Given these facts, we chose to use chocolate Easter Eggs as the main stimuli. Some manipulations were made in order to adapt the images to our conditions, as explained below.

The experimental design was adapted from the study of Fiszman et al. (2013), which presents four stimulus conditions for evaluating jelly pots: ingredient

\section{Revista Administração em Diálogo}

ISSN 2178-0080 
information, pot shape, jelly texture and the presence of the word "natural". This study, as it was already discussed, focuses on Easter eggs and presented three conditions for the evaluation of the participants. These were: (1) the presence or not of a gift; (2) the presence or absence of a cartoon or animated character; (3) the absence of both gifts and cartoon or animated characters, representing the preference for the chocolate only, already termed as the classic egg. This condition represents the eggs that use the same name and design of the chocolates in bars or in tablets that exist in the market, presenting diverse flavors of chocolates. The first and second conditions also had a subdivision of eggs representing products targeted for boys, girls or gender neutral.

Different types of Easter eggs were shown in the computer through images, and these stimuli were presented without a time limit, allowing free, untimed observation and choice of the egg in question. Furthermore, there was no distinction in the presentation of images for boys and girls (thus it is possible to test for genotypes of egg choice). The background of the images was white and the illumination was indirect, so as not to hinder data collection. The images were edited by a standard image editor so that the brand of the products was not divulged. The images were presented according to the conditions described above in a pseudorandom form. This means that the images varied in each trial position. No other information about the eggs were presented (company, weight, price, etc.). For example, the character could appear in any of the positions, as well as the other stimuli. 


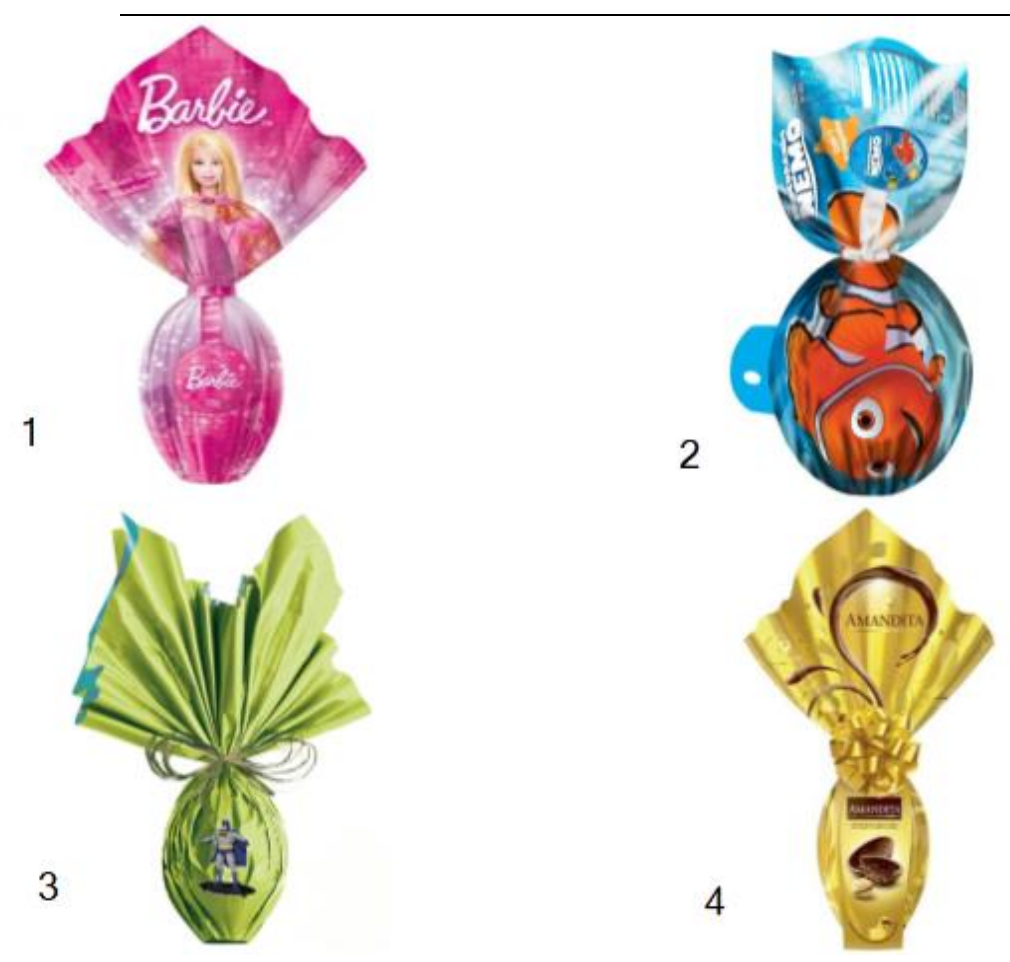

Image 1. Example of a trial

This trial contains four conditions as follows: feminine character (1), neutral character (2), male gift (3), and classic egg (4).

A total of 27 trials were presented containing four eggs in each trial, separated in three blocks to avoid boredom and fatigue. Each egg image was repeated three times during the experiment, so that the egg types were tested and compared with different options. They were not repeated more than three times so as to avoid learning and excessive repetition. In each trial, there was at least one classic egg, one egg in the neutral condition (character or gift) and one female egg (character or gift) or male (character or gift). There were variations among the blocks, with each one of which there were twelve classic eggs (without presenting any character or gift), eight eggs in the neutral condition (with character or gift but of neutral gender), eight male eggs (with character or gift), and eight female eggs (with character or gift).

\section{Procedure}

In a quiet room with standard lighting, after reading and signing the Assent Form, the procedure was explained for each child individually. The only relevant

\section{Revista Administração em Diálogo}

ISSN 2178-0080

Programa de Estudos Pós-Graduados em Administração 
information about the respondent was their age, which was asked before the images started to appear on the screen, according to the blocks delimited by the conditions. A test trial was done so that the participants could understand what would happen. They were also informed that they could ask questions at any time, as well as give up participation at any time without any kind of prejudice to them. All children had to do was to analyze the images presented and, after the end of each trial, choose the egg which they preferred. When all blocks were presented, the experiment was finished and children went back to class. Between the trials, a fixation cross with 2 seconds of duration appeared. Moreover, between the blocks there were messages stating the end of the block, so that children could rest for a moment.

\section{Ethical procedures}

This study was approved by the Research Ethics Committee of Univates (Coep / Univates), under number 1.956.834. It followed all the ethical procedures outlined in the Helsinki Declaration and is also in accordance with Brazilian National Health Council Resolution No. 466/12. All participants and their parents and / or guardians were informed about all aspects of data collection and received the Consent Form for reading and signing, just as children had to read and sign a Term of Assent. There was no recording of audio, video or any kind of data that could identify the participants. Participation in the research was totally voluntary and at any time before, during or after the collection, participants could request to drop out, without any kind of prejudice, and their data would be erased permanently. Data collection was only conducted in the presence of the researcher, a parent or guardian or school official duly authorized by a parent or guardian. This research did not entail financial costs or gains for the participants.

\section{Data Analysis}

Data was analyzed, so that there was a confrontation between the child's response on which egg they preferred and which attracted their attention during the visualization of the trials. A Repeated Measures ANOVA (Ime function in R) was used to analyze differences in choice and fixation measures. The areas of interest were created according to the conditions, as already mentioned: the gift, the character and

\section{Revista Administração em Diálogo}

ISSN 2178-0080

Programa de Estudos Pós-Graduados em Administração

Pontifícia Universidade Católica de São Paulo 
the classic egg. Choice, the number of fixations in each area of interest and the average duration of fixations in each area of interest were the variables used for data analysis.

\section{Results}

It was verified that, due to the low quality of collected data (as already exposed above) of five participants, these had to be excluded from data analysis, resulting in a total of 35 participants. Of 27 trials, on 20 of them the classic eggs were the most chosen by most of the participants, representing $70.37 \%$ of the choices, being that one of the times there was a tie between the classic egg and the neutral character. The second most chosen was the neutral character, appearing 5 times as the most chosen between the trials. The male gift, female character and male character were the most chosen only once. This means that neutral gifts and female gifts were not the most preferred in any of the trials. Considering the information only among female children, the classic egg was also the most chosen. In 21 occasions most of children chose the classic egg, and once there was a tie between classic and neutral character. The neutral character appeared four times as preferred by most of the girls. Lastly, the neutral gift appeared once as preferred by most. In any trial the male character, the male gift and the female gift were the most chosen.

In the case of male children, the preference remained with the classic egg with eleven choices, and in two occasions it ended up tied with the male character and the neutral character eggs. The male character followed, with six choices (counting the tie), followed by the male gift and the neutral character (counting the tie), both with four choices, and finally, neutral gift, with two choices. In the case of boys, the female character and female gift were not chosen as preferred by most in any of the trials. 
Table 1

Choice result by trial

\begin{tabular}{|c|c|c|c|}
\hline & Choice & $\begin{array}{c}\text { Choice - } \\
\text { Girls }\end{array}$ & $\begin{array}{c}\text { Choice - } \\
\text { Boys }\end{array}$ \\
\hline Classic egg & 20 & 21 & 13 \\
\hline Neutral character & 5 & 4 & 4 \\
\hline Male character & 1 & 0 & 6 \\
\hline Female character & 1 & 3 & 0 \\
\hline Male gift & 1 & 0 & 4 \\
\hline Neutral gift & 0 & 1 & 2 \\
\hline Female gift & 0 & 0 & 0 \\
\hline
\end{tabular}

The eyetracker data analysis confirmed the choice behavior shown above. The classic eggs received the most fixations. This type of egg averaged 98 fixations across the experiment and was the most fixated in 13 trials overall. Following the classic egg, the second most fixated egg was the male character (five trials overall) averaging 136 fixations overall. The neutral character followed, being the most fixated in four trials overall, averaging 113 fixations. Female character was most fixated twice and averaged 99 fixations. Neutral gift, averaging 59 fixations, was most fixated in only one trial. Female gift was not the most fixated in any trial. The fact that the classic egg has fewer average fixations than male and neutral characters might suggest that children could identify the egg more easily and thus did not have to explore the image to form his/hers preference.

Table 2

Fixation quantity per trial

\begin{tabular}{|l|r|r|}
\hline & $\begin{array}{c}\text { Most fixation quantity } \\
\text { per trial overall }\end{array}$ & $\begin{array}{c}\text { Average fixation } \\
\text { times overall }\end{array}$ \\
\hline Classic egg & 13 & 98 \\
\hline Male character & 5 & 136 \\
\hline Neutral character & 4 & 113 \\
\hline Female character & 2 & 99 \\
\hline Male gift & 2 & 91 \\
\hline Neutral gift & 1 & 59 \\
\hline Female gift & 0 & 0 \\
\hline
\end{tabular}


Although they had unlimited time to analyze each trial, the overall average fixation duration was 241.07 milliseconds (ms), or 0.24 seconds per fixation. It was also possible to analyze the average duration time that children looked at each egg. The prevalence of fixation duration in the analysis was set on a different type of egg. The type of eggs that children most fixated were male gifts, in nine trials and averaging 182.5 milliseconds, against the classic egg, which was most fixated in eight trials and averaged 153 milliseconds. Most fixated in six trials, the male characters eggs averaged 182.6 milliseconds, followed by neutral gift, (two trials and an average of 192.5 milliseconds); female character and neutral character were most fixated only once each averaging, respectively, 146 milliseconds and 227 milliseconds. Once again, the female gift was not the most fixated in any of the trials.

Table 3

Fixation duration per trial

\begin{tabular}{|l|r|r|}
\hline & $\begin{array}{c}\text { Most fixation duration per } \\
\text { trial overall }\end{array}$ & $\begin{array}{r}\text { Average fixation duration } \\
\text { (ms) }\end{array}$ \\
\hline Male gift & 9 & 182,5 \\
\hline Classic egg & 8 & 153 \\
\hline Male character & 6 & 182,6 \\
\hline Neutral gift & 2 & 192,5 \\
\hline Neutral character & 1 & 227 \\
\hline Female character & 1 & 146 \\
\hline Female gift & 0 & 0 \\
\hline
\end{tabular}

It is possible to note from the table above that the proximity of average fixation duration amongst areas of interest can suggest that, although quickly, children explored each egg with similar amounts of time. This point to the fact that there was a consideration of all options in each trial and that the choice could have been made considering the different options available. This behavior may also suggest that choice was consciously made, excluding the possibility of random choice or choosing the first available option in order to finish the experiment as soon as possible.

According to the Repeated Measures ANOVA, there is a significant difference between boys and girls in the mean fixation duration, $F(1,831)=5.40, p>0.05$. It was

\section{Revista Administração em Diálogo}

ISSN 2178-0080

Programa de Estudos Pós-Graduados em Administração 
also found that girls tend to fixate their gaze more on eggs with female characters $F$ $(1,184)=6,19, p>0,05$ and female toys $F(1,130)=10.75, p>0.05$ than the boys. However, when the same hypothesis is tested with males, it was noticed that no statistically significant difference is present for male toy or male character between the sexes. Analyzing the mean fixation duration, it was verified that there is a statistically significant difference between the different ages $F(3,829)=12,97, p>0,05$, and the younger children had less mean fixation duration in the eggs. The ANOVAs suggest that there is no significant difference when the whole sample is analyzed against fixation duration and fixation count. However, there are significant differences between boys and girls as to fixation in so called gender targeted strategies (female toys and characters) and between ages in fixation duration.

It is hypothesized that these results mean that children did explore the options available in a uniform fashion and that the preference is not directly correlated with fixation duration but rather on how many times children fixated on the eggs (as seen on tables 1 through 3 ). Moreover, the results suggest that children, although capable of comparisons between different aspects of the product, perform visual exploration of characteristics in little time. This may mean that their choice based on visual stimuli is made rather quickly and that indecision might not be a common factor (given the low number of fixation number).

\section{Discussion and Conclusion}

As previously seen, Silva and Vasconcelos (2012) identified characteristics related to the buying behavior of children according to their ages. By analyzing the ages at which the study was based, from seven to ten years old, these children already know how to identify and recognize brands, use flavor and functionality as criteria for choosing products and tend to be influenced by friends. Our results show that children in our sample preferred the classic chocolate egg, with no toys or characters, contrary to our main hypothesis. By classic chocolate eggs, as was previously explained, it is meant different flavored chocolates (milk, white, crispy, mixed flavored, etc.). On the other hand, eggs that featured characters and gifts are usually milk chocolate eggs. Thus, results suggest that children prefer to have different taste choices, and this 
attracts their choice and preference more than the characters or toys in the packaging alone. When Karsaklian (2012) affirms that children between seven and nine years old like to try new things, this suggests that they would prefer to have different chocolate flavors than the standard milk chocolate, which agrees with the experiment results.

Thus, it is shown that children who were part of the study do not agree with Silva and Vasconcelos (2012), who say that children often choose the product featuring particular character only because it appears on the packaging, without taking flavor, brand or functionality into account. According to Calvert (2008), marketers tend to display characters and offer gifts so children have a positive brand memory so they do not realize they are being attracted to a marketing campaign. On the other hand, Limeira (2008) affirms that from eight years old on, children already realize the persuasive intention that these campaigns have, so they might be more careful about them. Analyzing the time participants looked at each egg, the eggs with gifts were fixated most of the time, but even then, the classic eggs were the most chosen. This means that gifts did attract attention, however not enough to influence children's decisions. Karsaklian (2012) can explain this, when she affirms that children do not like to be offered a prize, because they would not change their favorite brand for a prize, which agrees with what they did in the experiment.

Silva and Vasconcelos (2012) also comment that affinity groups can be formed with children who like the same character. This was not seen in the study, as most children did not choose the egg because of the character or gift that appeared on the packaging. In this study, children chose the eggs individually and not in groups. It is hypothesized that this group effect is a part of daily contact with colleagues. Although there is always a group preferred character or hit toy, it is interesting to note that children probably did not make their choice with characters or toys in mind. Emotions are much more present in decisions than reason and, normally, emotional decisions are made in less time than other decisions. Since children presented mean fixation duration of 0.24 seconds per trial until they decided which eggs they liked the most, it might suggest that they used emotional associations to make their decisions. Considering what was seen in the ANOVAs, younger children showed a shorter fixation time than the older ones. This is consistent with Martorell (2014), when stating that the more children learn over the years, the more attention they dispose to a given

\section{Revista Administração em Diálogo}

ISSN 2178-0080 
situation. Bee and Boyd (2011) also say that close to five and six years old, children do not pay much attention to the appearance of objects, but rather in the underlying reality. This is consistent with the results found, as children opted for the classic eggs with different flavors and did not think much about the appearance of the chocolate egg carton.

The main objective of this study was to identify what most attracts children's attention when choosing an Easter egg, so this can help to aid the understanding of important factors in child consumer behavior. To do so, an eyetracker was used, which collected data from the participants' gaze and attention patterns regarding how they visualize the stimuli on the screen. Our main hypothesis was that the eggs with characters featured on the packaging were to be the most attractive to children and therefore were to be the most chosen. However, the results showed a different preference: the classic eggs were the ones most chosen by children from seven to ten years, implying that flavor is a very influential factor in their choice. The research was carried out with a sample of children, only in one school in the city of Lajeado, Brazil. Therefore, one of the limitations of the study is that it is not possible to extrapolate the results to all children. Another limitation was that they were in school hours during the experiment (they were called out of class and went to the experiment room), which may have hindered their attentional span during the experiment. Also, since the experiment was done with two children at the same time in the same room, they sometimes turned their heads to see the other colleague or tried to talk, taking their attention off the screen. Moreover, there is a possibility that the characters used in the images might not have adhered to the children that composed the sample. That could have hindered the attentional process and explain the choice for the classic egg.

For future research, it would be interesting to replicate this experiment with more children and from different places, and testing emotional measures such as electrodermal activity or electrocardiography alongside with the eyetracker. That may shed light on the actual influence of emotional processes in children's decision process. Complementary researches would be a next step to compare the results found in this study, using other products that also feature characters or gifts in the packaging, excluding, however, products that are not edible and do not have the taste factor to influence. Examples of said products may be: backpacks, beauty products (shampoo, 
conditioner and creams), clothes, school supplies, among others. Nonetheless, this study points to a discrepancy in what was considered a normal behavior in children Easter egg preference. That is an important information for marketers and parents given that can shed light on a unforeseen characteristic in children purchase preferences.

\section{References}

Acosta, C., Neumann, D.L., \& Neumann, M. M. (2014), Young children's visual attention to environmental print as measured by eye tracker analysis, Reading Research Quarterly, 49(2), 157-261.

Ariely, D., \& Berns, G. S. (2010). Neuromaketing: the hope and hype of neuroimaging in business, Nature Reviews Neuroscience, 11(4), 284-292.

Armstrong, G., \& Kotler, P. (2015). Princípios de Marketing. São Paulo: Pearson Education do Brasil.

Artissian, L., Cronemberger, R., \& Ribeiro, A. (2013). Especial Páscoa: Curiosidades, harmonizações e receitas. Available at: http://www.gastrovia.com.br/especial/31/ebook-especial-pascoa-2013

Bee, H., \& Boyd, D. (2011). A criança em desenvolvimento. Porto Alegre: Artmed Editora.

Calvert, S. L. (2008). Children as consumers: Advertising and Marketing, The future of children, 18(1), 205.

Camargo, P. C. J. (2013). Neuromarketing: a nova pesquisa de comportamento do consumidor. São Paulo: Atlas.

Costa, M.F., Lima, R.F., \& Santos, P. J. (2012). Comportamento do consumidor infantil: um estudo do consumo dos pais em supermercados através da influência dos filhos no momento da compra. Revista Administração em Diálogo, 14(2), 1-25.

Cyr, D., Head, M., \& Larios, H. (2010). Colour appeal in webdesign within and across cultures: A multi-method evaluation. International Journal of Human-Computer Studies, 68(1-2), 1-21.

Engelke, U., Darcy, D. P., Mulliken, G. H., Bosse, S., Martini, M. G., Arndt, S., Antons, J. N., Chan, K. Y., Ramzan, N., \& Brunnström, K. (2017). Psychophysiologybased QoE assessment: a survey. IEEE Journal of Selected Topics in Signal Processing, $11(1), 6-21$.

\section{Revista Administração em Diálogo}

ISSN 2178-0080 
Fiszman, B.P. et al. (2013). Using combined eye tracking and word association in order to assess novel packaging solutions: A case study involving jam jars. Food Quality and Preference, 28(1), 328-338.

Huang, Y.F., \& Kuo, F.Y. (2012). How impulsivity affects consumer decisionmaking in e-commerce. Electronic commerce Research and Applications, 11(6), 582590.

John, K., Lindsay, G., Peterson, E. B., \& Thomsen, S. (2010). Adolescents' attention to traditional and graphic tobacco warning labels: An eye-tracking Approach. Jornal of Drug Education, 40(3), 227-244.

Kail, R. V. (2004). A criança. São Paulo: Prentice Hall.

Karsaklian, E. (2012). Comportamento do consumidor. São Paulo: Editora Atlas.

Kotler, P., \& Keller, K. L. (2012). Marketing management. New Jersey: Prentice Hall.

Limeira, T. M. V. (2008). Comportamento do consumidor brasileiro. São Paulo: Saraiva.

Lukasova, K. (2012). Movimento ocular em crianças e adultos: estudo comparativo com uso integrado de RMf e Eye Tracking. Available at http://www.teses.usp.br/teses/disponiveis/5/5151/tde-07022013-104141/en.php

Manders, J. C. W., Pel, J. J. M., \& Steen, J. (2010). Assessment of visual orienting behaviour in young children using remote eye tracking: Methodology and reliability. Journal of Neuroscience Methods, 189(1), 252-256.

Martorell, G. (2014). O desenvolvimento da criança: do nascimento à adolescência. Porto Alegre: AMGH.

Mau, G., Schuhen, M., Steinmann, S., \& Schramm-Klein, H. (2016). How children make purchase decisions: behaviour of the cued processors. Young Consumers, 17(2), 111-126.

Morin, C. (2011). Neuromarketing: the new science of consumer behavior. Society, 48(2), 131-135.

Paixão, M. V. (2012). A influência do consumidor nas decisões de marketing. Curitiba: InterSaberes.

Silva, A. M. D., \& Vasconcelos, L. R. (2012). A criança e o marketing. São Paulo: Summus. 